\title{
Otitis Media and Language Performance in Learning Disabilities
}

\author{
N G Maritz, B Log (Pretoria) \\ I C Uys, D Phil (Pretoria) \\ B Louw, D Phil (Pretoria) \\ Department of Speech Therapy and Audiology \\ University of Pretoria
}

\begin{abstract}
This study was designed to determine the influence of otitis media on the language performance of learning-disabled children and nonlearning-disabled children.

Four experimental groups were used, viz: learning-disabled children, divided into those with and without a history of recurrent otitis media and average academic achievers again divided into those with and without a history of recurrent otitis media. The language performance of each experimental group was determined using the Clinical Evaluation and Language Function (Wiig and Semel, 1980). The results indicate that recurrent otitis media impaired the receptive and expressive language performance of the subjects used in this study. The impaiment of receptive language was greater than for expressive language. Implications for diagnosis, treatment and further research are discussed.
\end{abstract}

\section{OPSOMMING}

Hierdie studie is uitgevoer om die invloed van otitis media op die taalvermoëns van leergestremde kinders en nie-leergestremde kinders te bepaal.

Vier eksperimentele groepe is gebruik, nl. leergestremde kinders verdeel in dié met en sonder 'n geshiedenis van herhaalde otitis media en gemiddelde akademiese prestasies weer eens verdeel in dië met en sonder ' $n$ geskiedenis van herhaalde otitis media. Die taalvermoëns van elke ehsperimentele groep is bepaal met die "Clinical Evaluation of Language Function" (Wiig en Semel, 1980). Die resultate het getoon dat herhaalde episodes van otitis media ' $n$ negatiewe invloed het op die respektiewe en ekspressiewe taalvermoëns van die proef. persone gebruik in hierdie studie. Reseptiewe taalvermoëns is meer aangetas as ekspressiewe taalvermoëns. Implikasies vir diagnose, behandeling en verdere navorsing word bespreek.

\section{'}

Learning-disabled children exhibit specific communication problems and are at present referred to as "specific language impaired children" or "language learning impaired children" (Wiig and Semél, 1982; Sak and Ruben, 1982). These children have difficulty understanding or using language, spoken or written, which may lead to impaired ability to listen, think, speak, read, write, spell or do mathematical calculations.' Perceptual handicaps, brain injury, minimal brain dysfunction, dyslexia and development aphasia, also result in learning disabilities \{U.S. Office of Education, in Wiig and Semel, 1982). While the influence of otitis media on language development has been investigated, \{Kessler in Northern and Downs, 1984; Hornsby, 1984\} its influence on the language development of learning impaired children has, however, been neglected in the literature.

In an effort to list the specific language impairments exhibited by learning-disabled children, many authorities are inclined to fragment and oversimplify complex language processes and to disregard the interrelationship between them. Although the symptoms, as described in the literature, cannot be regarded as separate entities, the following impairments are mentioned:
Wallach and Butler [1984\} state that learning disabled children often have delayed or deviant auditory perception, synthesis, analysis, memory, discrimination and comprehension abilities. Difficulty with concept formation and metalinguistic skills, impoverished and delayed vocabulary skills and delayed rather than deviant language form are mentioned by Rapin (1979). Eisen (1962) and Gottlieb, Zinkus and Thompson (1979) add delayed phonological, morphological, and syntactic abilities, as well as poor divergent and convergent language production abilities. Wiig and Semel (1982) found that children with learning disabilities experience delays in achieving communication competence and developing mature styles and social register in interpersonal communication.

Within the framework of language learning disabilities, it is, however, clear that language cannot be separated from learning, aspects such as analysis and synthesis cannot be separated from auditory perception and language form, content and use cannot be separated from metalinguistic skills.

With regard to the influence that otitis media has on language development, research findings can be divided into two groups. The first group of researchers found that otitis 
media has a negative influence on language content and form. Children with recurrent otitis media were found to have poor auditory perception, decoding and discrimination abilities \{Eisen, 1962; Gottlieb, et al. 1979; Hugo, 1985; Sak and Ruben, 1982). These children also exhibit a higher incidence of delayed conceptualization, attention and soundblending abilities (Eisen, 1962; Kessler in Northern and Downs, 1984). According to Rapin (1979) these children have impoverished and delayed vocabulary. Children with recurrent otitis media were found to have reduced complexity of syntax, and exhibit phonological development delay. Learning impaired children are often poor readers according to Kessler in Northern and Downs (1984) and it is important to note that Hugo (1985) and Rapin [1979) found that children with recurrent otitis media are often low academic achievers at school.

The second group of researchers found that children with a history of otitis media, but whose hearing was normal at the time of testing, suffer little if any deficit, at least in terms of vocabulary, language comprehension, syntax and reading level (Owrid, 1970).

A possible explanation for the above-mentioned contradictory results is that single or infrequent bouts of middle-ear infection do not have a marked adverse effect on language and speech development or education progress (Mustain, 1979). Paradise (1983) has, however, stated that methodological weaknesses are present in the above-mentioned research. There is uncertainty about the validity of diagnosed otitis media reported as occurring in early life. There is an absence of information concerning the hearing-thresholds accompanying otitis media episodes and some subjects presented with otitis media at the time of testing. Further, the matching of subjects is questionable. Only a small number of subjects were tested and the tests used had questionable reliability.

It is interesting to note that recurrent otitis media may have an influence on neurological development. Studies have shown that the first five years are the most important for brain maturation, with particular emphasis on the second year. There is a critical period in neurological development when the brain is more susceptible to language acquisition (Vernon and Rothstein, 1968). The first four years form this critical period for the acquisition of language (Rubin, 1984). Webster (1984) found that the brains of animals with obstructed ear canals often do not mature normally. Hearing is thus essential for the development of the auditory pathways in the peripheral and central nervous system. This statement is alarming, as recurrent otitis media may thus impair the development of complex auditory functioning, as well as communicative and cognitive abilities /Hornsby, 1984).

The effect of recurrent otitis media on the language performance of learning-disabled children has been neglected in the literature. Literature has shown, (Van Rensburg, 1981), that learning-impaired children experience a higher incidence of recurrent otitis media than average academic achievers. The purpose of this study is to determine the effect of recurrent otitis media on the language performance of learning-disabled children, with normal hearing.

\section{METHODOLOGY}

\section{Subject selection}

352 questionnaires were distributed to 5 English Medium primary schools in Pretoria which have remedial classes. The questionnaires were completed by the parents of standard two pupils and collected by class teachers. Of the questionnaires distributed $82,5 \%$ were returned. $15,75 \%$ of the returned questionnaires could not be used due to the fact that they were incomplete or spoiled. The effective percentage of questionnaires that could be used was $69,88 \%$ and the effective number of potential subjects, 246 .

The 24 subjects used in this study were selected by using the Table of Random Numbers Method where "the purpose of randomness is to permit blind chance to determine the outcome of the selection process" (Leedy, 1985, p. 148). Six subjects were allocated to each experimental group (illustrated in table 1) with an even distribution of 3 male subjects and 3 female subjects per group. Subjects in experimental groups 1 and 3 were also required to satisfy Howie's definition in Northern and Downs $\{1984$, p. 13\}: "An otitis-pronechild has the condition 6 or more times before the age of 6 , or whose initial episode of otitis media was due to pneumococcus and occurred before the age of 1 year." This information was obtained from the questionnaires.

The subjects used English as their home language and had average intelligence, as indicated by the school files. They varied in age from 9 years 6 months to 10 years 3 months (the mean being 9 years 10 months). The experimental groups are described in table 1 . The learning-disabled children (experimental groups 1 and 2) showed a discrepancy between intellectual ability and academic achievement, as indicated by the school files. The non learning-disabled children (experimental groups 3 and 4 ) showed a correlation between intellectual ability and academic achievement, as indicated by the school files.

Table 1: Description of experimental groups $(n=24)$

\begin{tabular}{|c|c|c|c|}
\hline $\begin{array}{c}\text { GROUP } 1 \\
\{\mathrm{n}=6 \mid\end{array}$ & $\begin{array}{c}\text { GROUP } 2 \\
\{\mathrm{n}=6 \mid\end{array}$ & $\begin{array}{c}\text { GROUP } 3 \\
(\mathrm{n}=6)\end{array}$ & $\begin{array}{c}\text { GROUP' }_{4} \\
(\mathrm{n}=6)\end{array}$ \\
\hline $\begin{array}{l}\text { Learning- } \\
\text { disabled } \\
\text { children } \\
\text { with a histo- } \\
\text { ry of otitis } \\
\text { media }\end{array}$ & $\begin{array}{l}\text { Learning- } \\
\text { disabled } \\
\text { children } \\
\text { without a his- } \\
\text { tory of otitis } \\
\text { media }\end{array}$ & $\begin{array}{l}\text { Non-learning- } \\
\text { disabled } \\
\text { children } \\
\text { with a histo- } \\
\text { ry of otitis } \\
\text { media }\end{array}$ & $\begin{array}{c}\text { Non-learning- } \\
\text { disabled } \\
\text { children } \\
\text { without a his- } \\
\text { tory of otitis } \\
\text { media }\end{array}$ \\
\hline
\end{tabular}

\section{Apparatus and material}

\section{Questionnaire}

A questionnaire was compiled to select and allocate children to the four experimental groups required for the study. This questionnaire was used to determine the prevalence of otitis media among the subjects. The questionnaire was completed by parents.

The use of questionnaires in research have certain limitations. The researcher does not have direct access to the original data and the questionnaire is an impersonal probe (Leedy, 1980). The information obtained using questionnaires may thus have questionable reliability. Leedy (1985) provides practical guidelines to reduce impersonality and improve reliability. These 
guidelines include the usage of an initial letter, precise and simple language, courtesy, and 'easy to complete' questionnaire, the inclusion of countercheck questions and an offer of results to the respondent. The questionnaire utilized in this study, was compiled using these guidelines.

\section{Clinical Evaluation of Language Functions - CELF (Wiig and Semeli, 1980)}

The aim of the CELF is to provide differentiated measures of selected language functions in the areas of phonology, syntax, semantics, memory and word-finding and retrieval. These measures were designed to probe specific language processing and production abilities of school-age children. The subtests were designed to assist in the identification of children with learning disabilities, to provide a differential diagnosis of language areas involved through selected language probes and finally to identify areas which require language intervention. A summarized overview of the subtests is provided in table 2 . The CELF does, however, not provide an in-depth assessment of phonology or pragmatics /Wiig and Semel, 1980). The CELF consists of 3 groups of subtests, viz.: Language Processing, Production and Supplementary Subtests. In this study the Supplementary Subtests of the CELF (which assess phonology) are considered to form part of the Language Form/Production Subtests. This decision is supported by Bloom and Lahey (1978) who state that language form consists of 3 components, viz.: phonology, morphology and syntax. This decision will also facilitate the discussion of relevant related literature.

\section{Data collection procedure}

A Comparative Design was used. A comparison was made be tween the language performance of the four experimental groups of subjects on the CELF (Wiig and Semel, 1980). The
CELF norms have been standardised on the population of the United States of America. It was thus necessary to compare the language performance of subjects included in this study and the existing CELF norms. The research design consisted of a systematic evaluation of group differences where stimuli were controlled (Smit, 1983).

The 24 subjects were individually evaluated in their respective home situations. The tester followed the standardised instructions and administration procedures provided in the CELF Diagnostic Examiner's Manual (Wiig and Semel, 1980\}.

\section{Data analysis}

Subtests for each of the 24 CELF test forms were totalled, by adding the scores obtained for each item. This information was then statistically analysed by using an lBM $370 \mathrm{Compu}$ ter. The SAS Programme was utilized and procedures employed were the General linear models procedure, the Multiple analysis of variance method (with a 5\% level of significance) and Duncan's multiple range test (Ferguson, 1984). These procedures were used to compare the language performance of the four experimental groups.

\section{RESULTS}

The results entail an evaluation of the applicability of the CELF to the 4 experimental groups, a description of the level of language performance of each experimental group and an evaluation of intergroup tendencies.

\section{Evaluation of the applicability of the CELF to the 4 experimental groups}

Great caution should be exhibited when using the CELF to

Table 2: Summarized overview of the subtests of the CELF (Wiig, E. and Semel, E., 1980)

\begin{tabular}{|c|c|c|}
\hline \multicolumn{2}{|r|}{ SUBTESTS } & \multirow{2}{*}{$\begin{array}{l}\text { DESCRIPTION OF EACH SUBTEST } \\
\text { Assesses the child's ability to process and interpret selected word and sentence structures }\end{array}$} \\
\hline \multirow{13}{*}{ 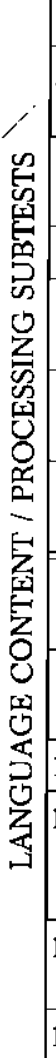 } & 1 Word and sentence structure & \\
\hline & 2 Word classes & $\begin{array}{l}\text { Evaluates the child's ability to perceive relationships between verbal concepts and identify } \\
\text { word pairs }\end{array}$ \\
\hline & 3 Linguistic concepts' & $\begin{array}{l}\text { Evaluates the ability to process and interpret oral directions which contain linguistic con- } \\
\text { cepts requiring logical operations }\end{array}$ \\
\hline & 4 Relationship and ambiguities & Evaluates the ability to process and interpret logico-grammatical and ambiguous sentences \\
\hline & 5 Oral directions & $\begin{array}{l}\text { Evaluates the accuracy, fluency, and speed in naming colours, forms, and colour-form } \\
\text { combinations in a sustained confrontation-naming task }\end{array}$ \\
\hline & 6 Spoken paragraphsi & $\begin{array}{l}\text { Evaluates the ability to process and interpret spoken paragraphs and recall salient informa. } \\
\text { tion presented }\end{array}$ \\
\hline & 7 Word series & $\begin{array}{l}\text { Assesses the accuracy, fluency and speed in recalling and producing selected automatic- } \\
\text { sequential word series }\end{array}$ \\
\hline & 8 Names on confrontation & $\begin{array}{l}\text { Evaluates the accuracy, fluency, and speed in naming colours, forms, and colour-form } \\
\text { combinations in a sustained confrontation-naming task }\end{array}$ \\
\hline & 9 Word associations & $\begin{array}{l}\text { Evaluates the quantity and quality of the retrieval of semantically related word series from } \\
\text { long-term memory }\end{array}$ \\
\hline & 10 Model sentences & Assesses productive control of sentence structure in a sentence repetition task \\
\hline & 11 Formulated sentences & $\begin{array}{l}\text { Evaluates the ability to formulate and produce sentences when word and sentence form } \\
\text { choices are limited and when semantic and syntactic constraints are introduced by a } \\
\text { word which has to be included }\end{array}$ \\
\hline & 12 Processing speech sounds & $\begin{array}{l}\text { Evaluates the ability to discriminate between speech sounds (phonemes) in minimally dif- } \\
\text { ferent word pairs }\end{array}$ \\
\hline & 13 Producing speech sounds & Evaluates the accuracy in articulating selected elicited speech sounds (phonemes). \\
\hline
\end{tabular}


evaluate the language performance of South African subjects. It is important to realize that the CELF norms are not necessarily representative of the South African population of school-age children. The CELF might for example be unable to identify learning-disabled children from average academic achievers, within the South African population. Furthermore, the CELF might identify non-existent problem areas in language or may be unable to identify these areas which will have a detrimental effect on the treatment and therapy process.

The language performance of experimental groups 1 and 2 [learning-impaired children| was significantly lower than the CELF norms. The differences between the language performance of experimental groups 3 and 4 (average academic achievers\} and the CELF were not significant.

A description and comparison of the language performance of experimental groups 1 and 2 on the CELF

The average performance or arithmetic mean of experimental groups 1 and 2 for each subject, together with the CELF norms are listed in table 2 . Table 3 indicates the CELF subtests for which the performance of experimental group 1 was significantly lower (at the $5 \%$ level of significance) than experimental group 2 .

Table 3: A summary of the CELF norms and the performance of the 4 experimental groups on each CELF subtest

\begin{tabular}{|c|c|c|c|c|c|c|}
\hline & \multirow[t]{2}{*}{ CELF SUBTESTS } & \multirow[t]{2}{*}{$\begin{array}{c}\text { STANDARDISED } \\
\text { CELF NORMS } \\
\text { USA } \\
\text { POPULATION }\end{array}$} & \multicolumn{4}{|c|}{$\begin{array}{c}\text { AVERAGE PERFORMANCE OF } \\
\text { ARITHMETIC MEAN OF EACH } \\
\text { EXPERIMENTAL GROUP [STANDARD } \\
\text { DEVIATION IN BRACKETS) }\end{array}$} \\
\hline & & & GROUP 1 & GROUP 2 & GROUP 3 & GROUP 4 \\
\hline 1 & Word and sentence structure & 38 & $\begin{array}{c}\{2,30\} \\
22^{*}\end{array}$ & $\begin{array}{l}\{2,88\} \\
34,6^{*}\end{array}$ & $\begin{array}{c}\mid 3,10\} \\
40\end{array}$ & $\begin{array}{c}(2,94) \\
36^{*}\end{array}$ \\
\hline 2 & Word classes & 30 & $\begin{array}{c}\{2,50\} \\
26^{*}\end{array}$ & $\begin{array}{c}\{2,68\} \\
30\end{array}$ & $\begin{array}{c}\{2,88\} \\
34,6\end{array}$ & $\begin{array}{c}(2,94) \\
36\end{array}$ \\
\hline 3 & Linguistic concepts & 34 & $\begin{array}{c}(2,40) \\
24^{*}\end{array}$ & $\begin{array}{c}\{2,73\} \\
31^{*}\end{array}$ & $\begin{array}{c}(3,06) \\
39\end{array}$ & $\begin{array}{c}(3,17) \\
42\end{array}$ \\
\hline 4 & Relationship and ambiquities & 36 & $\begin{array}{c}(2,30) \\
22^{*}\end{array}$ & $\begin{array}{c}(2,73) \\
31^{*}\end{array}$ & $\begin{array}{c}(3,14\} \\
41\end{array}$ & $\begin{array}{c}\{3,39\} \\
48\end{array}$ \\
\hline 5 & Oral directions & 32 & $\begin{array}{c}\{2,40\} \\
24^{*}\end{array}$ & $\begin{array}{c}(2,23) \\
25^{*}\end{array}$ & $\begin{array}{c}\{3,18\} \\
40\end{array}$ & $\begin{array}{c}{[3,06\}} \\
39\end{array}$ \\
\hline 6 & Spoken paragraphs & 8 & $\begin{array}{c}\{1,00\} \\
4^{*}\end{array}$ & $\begin{array}{c}\{1,30\} \\
7^{*}\end{array}$ & $\begin{array}{c}\{1,37\} \\
7,8^{*}\end{array}$ & $\begin{array}{c}\{1,77\} \\
13\end{array}$ \\
\hline 7 & $\begin{array}{l}\text { Word series: item } 1 \text { accuracy } \\
\text { Time for item } 1\end{array}$ & $\begin{array}{l}7 \\
10\end{array}$ & $\begin{array}{c}\{1,10\} \\
5^{*} \\
\{2,19\} \\
20\end{array}$ & $\begin{array}{c}\{1,30\} \\
7 \\
\{2,14\} \\
19\end{array}$ & $\begin{array}{c}\{1,30\} \\
7 \\
(1,50) \\
9^{*}\end{array}$ & $\begin{array}{l}(1,30) \\
7 \\
(1,20) \\
6^{*}\end{array}$ \\
\hline & $\begin{array}{r}\text { Word series: item } 2 \text { accuracy } \\
\text { Time for item } 2\end{array}$ & 20 & $\begin{array}{l}\{1,00\} \\
4^{*} \\
(2,58) \\
27,6\end{array}$ & $\begin{array}{c}(1,20) \\
6^{*} \\
(2,73) \\
31\end{array}$ & $\begin{array}{c}(1,70) \\
12 \\
(2,14) \\
19^{*}\end{array}$ & $\begin{array}{c}\{1,70\} \\
12 \\
\{1,55\} \\
10^{*}\end{array}$ \\
\hline 8 & Confrontation naming & 32 & $\begin{array}{c}{[2,45]} \\
25^{*}\end{array}$ & $\begin{array}{c}\{2,37\} \\
23^{*}\end{array}$ & $\begin{array}{c}\{2,91\} \\
35\end{array}$ & $\frac{\{2,86\}}{34}$ \\
\hline & Time & 100 & $\begin{array}{l}\{4,40\} \\
80,6^{*}\end{array}$ & $\begin{array}{l}\{4,94\} \\
110,5\end{array}$ & $\begin{array}{l}(4,96) \\
112,5\end{array}$ & $\begin{array}{c}(4,90) \\
100\end{array}$ \\
\hline 9 & Word associations & 20 & $\begin{array}{c}(1,55) \\
10^{*}\end{array}$ & $\begin{array}{c}\langle 1,64\} \\
11^{*}\end{array}$ & $\begin{array}{c}(2,50) \\
26\end{array}$ & $\begin{array}{c}(2,45) \\
25\end{array}$ \\
\hline 10 & Model sentences & 36 & $\begin{array}{c}(2,19) \\
20^{*}\end{array}$ & $\begin{array}{c}(2,59) \\
28^{*}\end{array}$ & $\begin{array}{c}(3,50) \\
51\end{array}$ & $\begin{array}{c}{[3,79] !} \\
60\end{array}$ \\
\hline 11 & Formulated sentences & 25 & $\begin{array}{c}\{2,35\} \\
23^{*}\end{array}$ & $\begin{array}{c}\{2,64\} \\
29\end{array}$ & $\begin{array}{c}\{2,98\} \\
37\end{array}$ & $\begin{array}{c}(3,06) \\
39\end{array}$ \\
\hline 12 & Processing & 115 & $\begin{array}{c}\{5,09\} \\
118\end{array}$ & $\begin{array}{c}\{5,25\} \\
115\end{array}$ & $\begin{array}{c}\{5,30\} \\
117\end{array}$ & $\begin{array}{c}\{5,25\} \\
115\end{array}$ \\
\hline 13 & Producing speech sounds - blends & 50 & $\begin{array}{c}\{3,53\} \\
52\end{array}$ & $\begin{array}{c}(3,53) \\
52\end{array}$ & $\begin{array}{c}(3,35) \\
50\end{array}$ & $\begin{array}{c}\{3,53\} \\
52\end{array}$ \\
\hline & Producing speech sounds - final position & 18 & $\begin{array}{c}(2,08) \\
18\end{array}$ & $\begin{array}{c}(2,08) \\
18\end{array}$ & $\begin{array}{c}(2,08) \\
18\end{array}$ & $\begin{array}{c}\{2,08\} \\
18\end{array}$ \\
\hline & Production speech sounds - initial position & 20 & $\begin{array}{c}(2,19) \\
20 \\
\end{array}$ & $\begin{array}{c}\{2,19\} \\
20\end{array}$ & $\begin{array}{c}{[2,19]} \\
20\end{array}$ & $\begin{array}{c}\{2,19\} \\
20\end{array}$ \\
\hline
\end{tabular}

KEY:

* Language performance of that specific experimental group was lower than the CELF norm for the subtest STANDARD DEVIATION. 
$A$ description and comparison of the language performance of experimental groups 3 and 4 on the CELF

The average performance or arithmetic mean of experimental groups 3 and 4 for each subtest, together with the CELF norms are listed in table 2 . Table 4 indicates the CELF subtests for which the performance of experimental group 3 was significantly lower (at the $5 \%$ level of significance) than experimental group 4.

Table 4: The comparison of the language performance of experimental groups 1 and 2

\begin{tabular}{|l|c|}
\hline CELF SUBTESTS & $\begin{array}{c}\text { COMPARISON OF } \\
\text { THE LANGUAGE } \\
\text { PERFORMANCE OF } \\
\text { EXPERIMENTAL } \\
\text { GROUPS 1 AND 2 }\end{array}$ \\
\hline 1 Word and sentence structure & \\
2 Word classes & $*$ \\
3 Linguistic concepts & $*$ \\
4 Relationship and ambiguities & \\
5 Oral directions & $*$ \\
6 Spoken paragraphs & \\
7 Word series: item 1 accuracy & \\
Time for item 1 & $*$ \\
$\quad$ Word series: item 2 accuracy & \\
8 Time for item 2 & \\
$\quad$ Time & \\
9 Word associations & \\
10 Model sentences & \\
11 Formulated sentences & \\
12 Processing speech sounds & \\
13 Producing speech sounds & \\
- blends & \\
Producing speech sounds & \\
- final position & \\
Producing speech sounds & \\
- initial position & \\
KEY. & \\
\hline
\end{tabular}

* Performance of group 1 (at the 5\% level of significance) was significantly lower than group 2 for the specific subtest.

\section{DISCUSSION}

The CELF norms were standardised on a USA population of school-age children. The evaluation of the applicability of the CELF to the South African population, has indicated that the CELF is applicable to experimental groups 3 and 4 , and thus the average academic achievers in this study. It is important to realize the the CELF was standardised by using a group of 100 subjects, while experimental groups 3 and 4 consisted of 6 subjects each. The sample population used in this study might not reflect the characteristics resident in the general population accurately. This conclusion is supported by Leedy (1985), who states that the larger the sample, the higher the degree to which the sample population will approximate the qualities and characteristics resident in the general population. The preceding discussion has indicated that the CELF (Wiig and Semel, 1980) appears to be a reliable instrument for the identification of learningdisabled children within the South African population. The CELF norms were also found to be representative of the average academic achievers in this study.
Table 5: The comparison of the language performance of experimental groups 3 and 4

\begin{tabular}{|l|c|}
\hline CELF SUBTESTS & $\begin{array}{c}\text { COMPARISON OF } \\
\text { THE LANGUAGE } \\
\text { PERFORMANCE OF } \\
\text { EXPERIMENTAL } \\
\text { GROUPS 3 AND 4 }\end{array}$ \\
\hline 1 Word and sentence structure & \\
2 Word classes & \\
3 Linguistic concepts & \\
4 Relationship and ambiguities & \\
5 Oral directions & \\
6 Spoken paragraphs & \\
7 Word series: item 1 accuracy & \\
$\quad$ Time for item 1 & \\
$\quad$ Word series: item 2 accuracy & \\
$\quad$ Time for item 2 & \\
8 Confrontation naming & \\
$\quad$ Time & \\
9 Word associations & \\
10 Model sentences & \\
11 Formulated sentences & \\
12 Processing speech sounds & \\
13 Producing speech sounds & \\
- blends & \\
Producing speech sounds & \\
- final position & \\
Producing speech sounds & \\
- initial position & \\
KEY: & \\
* Performance of group 3 at the 5\% level of significance) was \\
significantly lower than group 4 for the specific subtest.
\end{tabular}

The inter-group tendencies of the four experimental groups will now be discussed, but as the purpose of the study was not to give an in-depth identification of individual characteristics, this will not be included in this discussion. It is interesting to note that the Language Content/Processing Subtests on which experimental groups 3 and 4 differed, also occurred in those subtests for which experimental groups 1 and 2 differed. Experimental groups 1 and 3 thus exhibited lower levels of language performance than experimental groups 2 and 4 for the CELF Language Content/Processing Subtests. Experimental groups 1 and 3 consisted of subjects with a history of recurrent otitis media, implying the presence of the fluctuating hearing loss. The presence of a fluctuating hearing loss does not permit the subject with recurrent otitis media to adapt to constant auditory perceptions. This in turn inhibits the development of normal perceptual abilities and may influence language development negatively (Kessler, in Northern \& Downs, 1984). The difference exhibited by experimental groups 3 and 4 for the Language Content/Processing Subtests was not as great as the difference exhibited by experimental groups 1 and 2 . This can be attributed to the fact that experimental group 3 consisted of subjects with average academic achievement. Another reason may be that learning-disabled children may be genetically more susceptible to language and learning problems \{Teele, Klein \& Rosner, 1980\}. This factor, together with a history of otitis media, may have a more severe influence on language performance.

Downs (1977) states that recurrent otitis media may result in a syndrome referred to as "Irreversible-Auditory-Learning. 
Disaster" and emphasizes that language and learning skills, especially those based on auditory functions are irreversibly damaged by otitis media. The question that poses itself is whether learning-disabled children have a higher incidence of otitis media than children with average academic achievement. Research performed by Van Rensburg (1981) indicated that learning-disabled children have a remarkably higher incidence of otitis media than children with average academic achievement. Further research is, however, necessary to confirm this statement.

It is interesting to note that the Language Form/Production Subtests on which experimental groups 1 and 2 differed are the same as on subtests on which experimental groups 3 and 4 differed. Experimental groups 1 and 3 exhibited lower levels of language performance than experimental groups 2 and 4 for the CELF Language Form/Production Subtests. Recurrent otitis media appears to exert a negative influence on language form in experimental groups 1 and 3. Language form is based on, and also develops simultaneously with language content (Bloom and Lahey, 1978). A deficit, deviancy or delay in language content will thus influence the development of language form. In experimental groups 1 and 3 (subjects with a history of otitis media) the presence of a fluctuating hearing loss due to recurrent episodes of otitis media had a marked negative influence on the language form of experimental groups 1 and 3 .

Bloom and Lahey (1978, pp. 23) state that "Children learn language as they use language both to produce and understand messages." Language form problems, caused by recurrent otitis media are usually subtle and are difficult to identify unless the child is tested formally (Bloom and Lahey, 1978; Rapin, 1979). This factor may account for the fact that the Language Form Subtests, for which experimental groups 1 and 2 differed, are identically reflected in the results of experimental groups 3 and 4. The CELF /Wiig and Semel, 1982) might not be an instrument that is sensitive enough to identify differences between the experimental groups in this study. According to Wiig and Semel (1982) the results of the CELF should be complemented by the administration of standardized measures of receptive vocabulary development and an analysis of the spontaneous speech sample.

The results of this study indicate that recurrent otitis media has a negative influence on language content and form, as has been demonstrated by experimental groups 1 and 3 . The influence of recurrent otitis media on the language perform. ance of learning-disabled children has not been evaluated previously. Although the size of the population tested in this study was limited, the results indicate that recurrent otitis media may have an adverse effect on the language performance of learning-disabled children. The sample population used in this study might not reflect the characteristics resident in the general population accurately, as the larger the sample, the higher the degree to which the sample population will approximate the qualities and characteristics resident in the general population.

The results of this study are important from a clinical point of view. It is essential that Speech Pathologists and Audiologists realise the implications that recurrent otitis media may have on the language performance of learning-disabled children, as well as children with average academic achievement. Extensive benefits would be gained if recurrences of otitis media could be prevented or substantially reduced in frequency (Northern and Downs, 1984). Paradise (1980) has suggested five different ways in which the incidence of otitis media episodes may be reduced, viz. adenoidectomy with or without tonsillectomy; antimicrobial prophylaxis; the use of tympanostomy tubes, the frequent and liberal use of myringotomies; and polyvalent pneumococcal vaccine.

Current literature and the results of this study stress that the clinician should obtain information concerning the occurrence and incidence of otitis media for all children evaluated. This will enable the Speech Therapist/Audiologist to identify at risk children and also extend existing knowledge, concerning the influence that otitis media has on language performance.

This study represents the implementation of an exciting recent research direction that should be explored. Recommendations for further research are:

- To conduct a similar study, using a larger sample, in order to reflect the characteristics of the general population more accurately.

- To determine whether children with certain craniofacial characteristics may make them more prone to recurrent otitis media. Sharon (1985) suspects that these children have comparatively elongated faces, similar to the findings reported by Bresolin, Shapiro and Shapiro (1984) in children with chronic nasal construction, who breathe through their mouths.

- The standardisation of the CELF on different language groups in South Africa.

\section{CONCLUSION}

This study indicates that the CELF appears to be applicable to the South African population of English-speaking schoolage children. The CELF also appears to be a reliable instrument for the identification of learning-impaired children within the South African population. Further research is, however, necessary in order to standardize this test for the South African population.

Recurrent otitis media appears to have a negative influence on the language content and form of learning-disabled children and children with average academic achievement.

Further research with a larger sample population is necessary to confirm these research findings.

\section{REFERENCES}

Bloom, L. and Lahey, M. Language development and language disor. ders. New York: Wiley, 1978.

Bresolin, D., Shapiro, G.G. and Shapiro, P.A. Facial characteristics of children who breathe through the mouth. Pediatrics, 73 , 622-625, 1984.

Downs, M.P. The expanding imperatives of early identification in Bess, F.H. (Ed): Childhood Deafness: Causation, Assessment and Management. New York: Grune and Stratton, 1977

Eisen, N.H. Some effects of early deprivation on later behaviour: the quandom hard of hearing child. Journal of Abnormal Social Psychology, 65, 338,1962.

Ferguson, G.A. Statistical Analysis in Psychology and Education. Singapore: McGraw-Hill, Inc., 1984. 
Gottlieb, M.E. Zinkus, P.W. and Thompson, M.A., Chronic middle-ear disease and auditory perceptual deficits. Clinical Pediatrics, $18\{12\}, 725-732,1979$.

Hornsby, B. Overcoming Dyslexia. Kenwyn: Juta and Co., Ltd., 1984.

Hugo, R. Normatiewe evaluasies van otitis media as sekondêre pa tologie. Opwoeding (Suid-Afrikaanse Tydskrif), 5(2), 83-88, 1985.

Leedy, P.D. Practical Research Planning and Design. New York: Mac-Millan Publishing Company, 1985.

Mustain, W.D. Linguistic and educational implications of recurrent otitis media. Ear, Nose and Throat Journal, 58, 62-68, 1979.

Northern, J.L. and Downs, M.P. Hearing in Children. Baltimore, Maryland: The Williams and Wilkins, Co., 1984.

Owrid. H.L. Hearing impairment and verbal attainment in primary school children. Education Research, 12, 209-214, 1970.

paradise, J.L. Otitis media in infants and children. Pediatrics, 65, $917-943,1980$.

Paradise, J.L. Long term effects of short term hearing loss Menace or myth? Pediatrics, 71, 647-648, 1983.

Rapin, I. Conductive hearing loss. Effects on children's language and scholastic skills. A review of literature. Annals of Otology, Rhinology and Laryngology, 88, (Supplement 60), $3-12,1979$.

Rubin, R.J. The effects of recurrent middle ear effusion in preschool years on language and learning. Audiology in Practice,
1 (Supplement 3), 5-7, 1984.

Sak, R.J. and Rubin, R.J. Effects of recurrent middle ear effusion in pre-school years on language and learning. Journal of Developmental and Behavioural Pediatrics, 3, 7-77, 1982

Sharon, B.J. The face in otitis media. Pediatrics, $75,131,1985$.

Smit, G.J. Navorsingsmetodes in Gedragswetenskappe. Pretoria: HAUM opvoedkundige uitgewers, 1983.

Teele, D.W. Klein, J.O. and Rosner, B.A. Epidemiology of otitis media in children. Annals of Otology, Rhinology and Laryngology, 89, 5-6, 1980.

Van Resnburg, Y.J. Chroniese otitis media by die kind met leerpro. bleme. Voorkoms en gevolge. Unpublished research study (B.Log). University of Pretoria, 1981.

Vernon, M. and Rothstein, P. Prelingual deafness. Archives of General Psychiatry, 19, 361-367, 1968.

Wallach, G.D. and Butler, K.G. Language Learning Diabilities in School-age Children. London: Williams and Wilkins, Co. 1984

Webster, D.B. The effects of recurrent middle-ear effusion in pre school years on language and learning. Audiology in Practice, 1 (Supplement 3), 2, 1984.

Wiig, E.H. and Semel, E.M. Clinical Evaluation of Language Function. Columbus, Ohio: Charles E. Merrill Publishing Company, 1980.

Wiig, E.H. and Semel, E.M. Language Assessment and Learning Disabled. Toronto: Merrill Publishing Company, 1982.

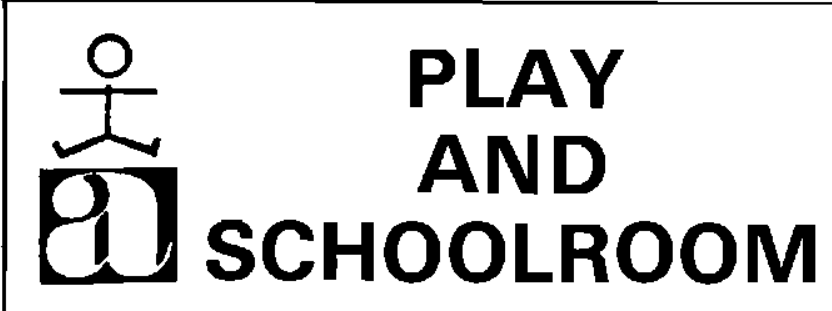

\title{
HAVE MOVED TO BIGGER AND BETTER PREMISES
}

\author{
AT \\ SHOP 6L THE ROSEBANK MEWS \\ 173 OXFORD ROAD \\ ROSEBANK JHB.
}

PLAY \& SCHOOLROOM, specialists in the field of child education have been offering assistance to both professionals and parents for nearly thirty years.

Their expertise and advice range through pre-school education, perceptual training, primary and remedial education and adult education.

Play and Schoolroom are sole agents for learning development aids which includes an excellent selection of materials of interest to the speech therapist. They also offer an interesting range of aids and books to foster and develop language and communicative skills.

Their stock of educational books and toys is exceptionally wide. You are invited to view their superb range in their new beautifully laid out showroom.

PHONE 788-1304

PO BOX 52137 (as before)

SAXONWORLD 2132 


\section{A LEGACY \\ OF SOUNDADVICE AND EQUIPMENT}

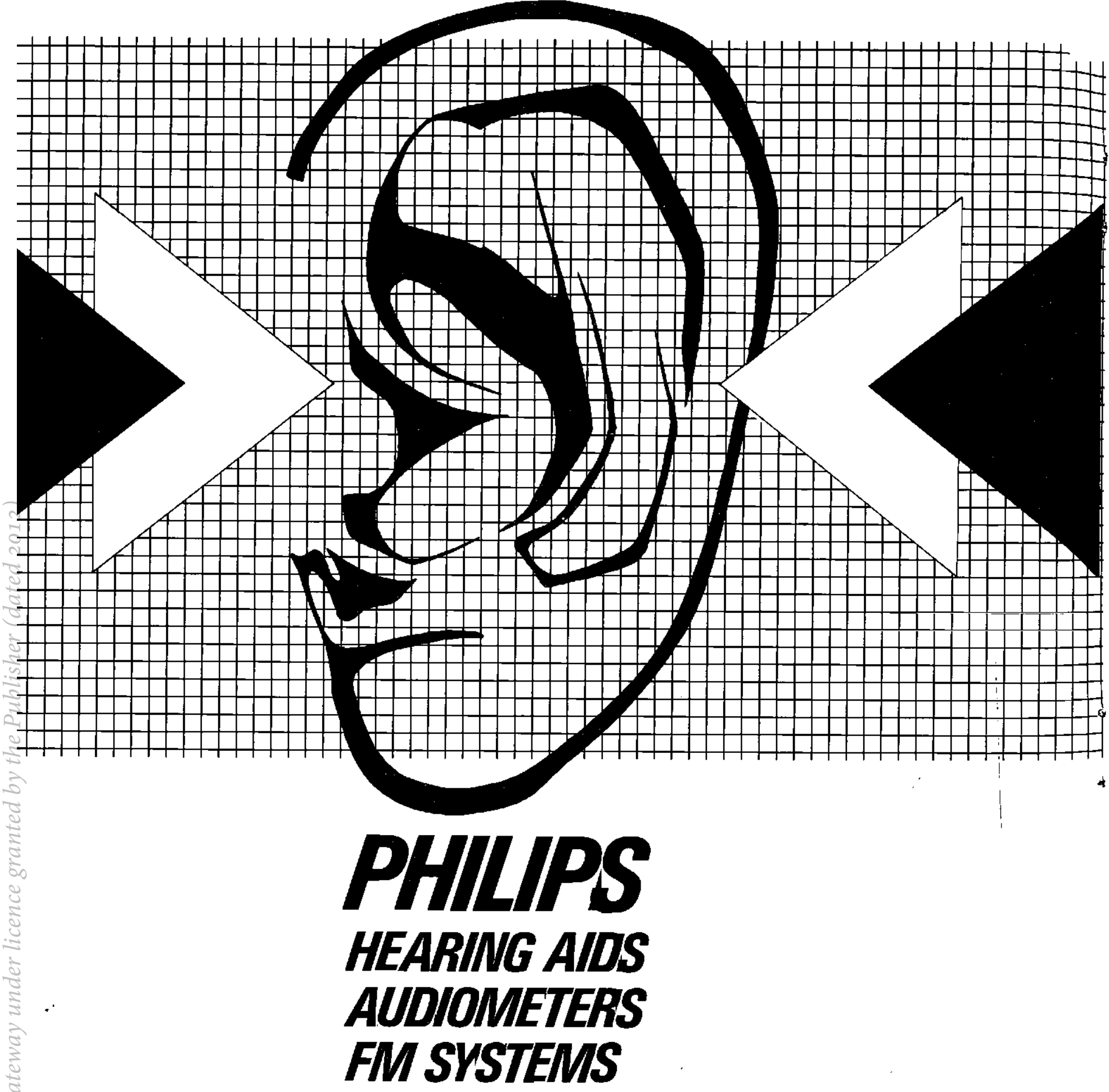

Head Office: 1005 Cavendish Chambers, 183 Jeppe Street

P.O. Box 3069, Johannesburg 2000. Tel: (011) 337.7537. 